\title{
Retrospective Analysis of Demographic and Laboratory Data of Patients with Hepatocellular Carcinoma: Single Center Experience
}

\section{Hepatosellüler Kanserli Hastaların Demografik ve Laboratuar Verilerinin Retrospektif Analizi: Tek Merkez Deneyimi}

\author{
Murat Bardakçı1 ${ }^{1}$, Yakup Ergün ${ }^{2}$, Kendal Yalçın³ \\ ${ }^{1}$ Diyarbakır Silvan Dr. Yusuf Azizoğlu Devlet Hastanesi, İç Hastalıkları Kliniği \\ ${ }^{2}$ SBÜ Ankara Numune Eğitim Ve Araştırma Hastanesi, Tıbbi Onkoloji Bölümü \\ ${ }^{3}$ Dicle Üniversitesi Tıp Fakültesi, Gastroenteroloji Bilimdalı, Diyarbakır
}

Dergiye Ulaşma Tarihi: 01.07.2018 Dergiye Kabul Tarihi:13.09.2018 Doi: 10.5505/aot.2019.69672

\begin{abstract}
ÖZET
GİRIŞ ve AMAÇ: Hepatosellüler kanser (HSK) sıklıkla kronik karaciğer hastallğı ve siroz zemininde gelişen agresif bir tümördür. Bölgemizde farklı etyolojilere bağlı olarak gelişen hepatosellüler kanserin epidemiyolojik, klinik ve tümör özelliklerinin karşılaştırmalı olarak incelenmesi amaçlandı.

YÖNTEM ve GEREÇLER: 2000-2015 yılları arasında hastanemiz gastroenteroloji bölümüne başvuran 18 yaş ve üstü, uluslararası kabul görmüş histolojik veya non-invazif kriterlere göre (EASL, AASLD) HSK tanısı olan hastalar çalışmaya dahil edildi. Çalışmaya 377 hasta alınmış olup demografik, klinik ve laboratuar verileri retrospektif analiz edildi. Hastalar etyolojik nedenlerine göre gruplandırıldı.

BULGULAR: Hastaların yaş ortalaması $58.70 \pm 12.50$ yıl olup, \%82.2'si erkekti. Hastaların büyük çoğunluğu şehir merkezinde yaşamakta olup, \%67.6'sının eğitim seviyesi ilkokul veya daha düşük seviyedeydi. Hastaların \%87'sinde HSK'nın siroz zemininde geliştiği görüldü. Etiyolojik nedenlere baktığımızda ise hastaların \%57.8'i HBV'ye, \% 15.6's1 HDV'ye, \% 8.2'si HCV'ye, \% 18.3'ü non-viral nedenlere bağlı geliştiği görüldü. Viral etiyolojilere bağlı HSK gelişen hastalarda ortalama enfeksiyon süresi $9.38 \pm 9.08$ yıl olup, \% 23.6's1 antiviral tedavi almaktaydı. Hastaların \%72'sinin Child-Pugh skoru B ve C olarak değerlendirildi.

TARTIŞMA ve SONUÇ: Viral hepatitler, HSK gelişiminde en önemli risk faktörü olup, HSK sıklıkla siroz zemininde gelişmektedir. Bu nedenle kronik viral hepatitli ve siroz hastalarının takip ve taraması büyük önem taşımaktadır. Bölgemizde HSK'lı hastaların anti-viral tedavi kullanma oranlarının düşüklüğ̈̈ ve yüksek ChildPugh skoru ile başvurmaları bu konunun hala önemini koruyan ciddi bir sağlık problemi olduğunu göstermektedir. Viral hepatitler ile ilgili farkındalığın arttırılması, aşı programlarına hastaların teşviki ile HSK prevalansının azaltılacağı aşikar olup, siroz gelişen hastalarda da düzenli takip programlarıyla daha erken evrede HSK tanısı konup daha efektif tedavi seçenekleriyle uzun süreli sağ kalım elde edilecektir.
\end{abstract}

Anahtar Kelimeler: Hepatosellüler karsinom, etiyoloji, kronik viral hepatit, siroz

\section{ABSTRACT}

INTRODUCTION: Hepatocellular carcinoma (HCC) is an aggressive tumor that frequently occurs in the setting of chronic liver disease and cirrhosis. In this study, we aim to evaluate the etiologic factors associated with Hepatocellular carcinoma and their role on the clinical outcome and prognosis of the disease. METHODS: A total of 377 patients were included in the study. Patient files were retrospectively analyzed. HCC was diagnosed based on radiologic, histologic, clinical and laboratory findings. Patients were grouped according to etiology.

RESULTS: The mean age of the patients was $58.70 \pm 2.50$ years and $82.2 \%$ of them were male. The vast majority of the patients were living in the city center, and $67.6 \%$ of them had primary education or lower education level. It was seen that HCC developed in cirrhosis base in $87 \%$ of the patients. When we looked at the etiologic factors, $57.8 \%$ of the patients were found to develop due to HBV, $15.6 \%$ to $\mathrm{HDV}, 8.2 \%$ to $\mathrm{HCV}$ and $18.3 \%$ to non-viral causes. The mean duration of infection was $9.38 \pm 9.08$ years and $23.6 \%$ were taking antiviral treatment in patients with HSC due to viral etiology. 
DISCUSSION AND CONCLUSION: Viral hepatitis is the most important risk factor for the development of HCC, and HCC often develops on the basis of cirrhosis. Therefore, the follow up and treatment of patients with chronic viral hepatitis and cirrhosis is of great importance. Patients with HCC in our region with low rates of anti-viral treatment and high Child-Pugh score suggest that this is still a serious health problem that is still important. Increased awareness of viral hepatitis is evident when the incidence of $\mathrm{HCC}$ is reduced by vaccination programs, and patients with cirrhosis will be diagnosed with HCC at an earlier stage with regular follow-up programs and will have a long-term survival benefit with more effective treatment options.

Keywords: Hepatocellular carcinoma, etiology, chronic viral hepatitis, cirrhosis

\section{GíRIŞ}

Hepatosellüler karsinom (HSK), karaciğerin en sık görülen primer malign tümörü olup dünya çapında erişkin erkeklerde en sık saptanan beşinci ve yetişkin kadınlarda en yaygın dokuzuncu kanserdir (1). HSK dünyadaki kansere bağlı ölümlerin dördüncü önde gelen nedenidir (2).

Hemen hemen bütün popülasyonlarda HSK erkeklerde kadınlardan daha fazla görülmekte olup erkek/kadın oranı 2:1 ile 4:1 arasında değişmektedir (3). HSK'lerin çoğunluğu kronik karaciğer hastalı̆̆ veya sirozu olan hastalarda görüldüğünden uzun süredir devam eden karaciğer hastalığı olan yaşlı hastalarda HSK görülmesi daha olasıdır. Hem Asya hem de Batı Avrupa'da yapilan birkaç büyük prospektif çalışma, HSK görülme yaşını ortalama 50-60 yaş olarak bildirmişlerdir (4-5).

HSK insidansı coğrafi bölgeye göre büyük oranda değişmektedir (6). HSK vakalarının \%80'inden fazlası Sahra Alt1 Afrika ve Doğu Asya'da bulunmaktadır. HSK gelişimi için çeşitli önemli risk faktörleri tanımlanmıştır. Bunlar arasında hepatit B virüsü (HBV) enfeksiyonu, kronik hepatit $\mathrm{C}$ virüsü (HCV), alkol, aflatoksin maruziyeti, non-alkolik stetohepatit (NASH) ve neredeyse her nedene bağlı siroz bulunur (7). Dünya genelinde 2012 y1lında meydana gelen 770.000 HSK vakası analizinde, vakaların \%50'sinden fazlası kronik HBV'ye atfedilmiş ve vakaların \%20'si HCV enfeksiyonuna bağlanmıştır (8). HBV ve aflatoksine bağlı HSK doğu toplumlarında sık görülürken $\mathrm{HCV}$, alkol ve NASH'e bağlı HSK batı toplumlarında daha sık görülmektedir. Türkiye'de de HSK sıklıkla daha ileri yaşlarda ve sirotik karaciğer zemininde gelişmektedir. Kronik HBV, HCV ve HDV enfeksiyonu HSK gelişimindeki en önemli etyolojik faktördür (9-10).

HSK tanisinda yaygin olarak kullanılan klavuzlar European Association for the Study of the Liver (EASL), American Association for the Study of Liver Disease (AASLD) ve Asian Pacific Society for the Study of the Liver (APASL)'dır (11). Güncellenen klavuzlarda radyolojik tetkiklerdeki tipik görüntü yeterli bulunmaktadır. AFP seviyesi tanıya yardımcı olabilmekte ancak tanı için AFP yüksekliği gerekli değildir. Radyolojik olarak HSK kriterlerini yerine getiren bir hastada histolojik onay gerekli değildir. Radyolojik olarak kesin tanı koyulamıyorsa ve sonuçları hastanın yönetimini etkileyecekse biyopsi yapılmalıdır. Bölgemizde farkl1 etiyolojilere bağlı olarak gelişen HSK'nın epidemiyolojik, klinik ve tümör özelliklerinin karşılaştırmalı olarak incelenmesi amaçland.

\section{MATERYAL ve METOD}

Bu çalışmaya 2000-2015 yılları arasında Dicle Üniversitesi Tıp Fakültesi, Gastroenteroloji Bilim dalına başvuran HSK tanılı hastalar alındı. 18 yaş ve üstü, uluslararası kabul görmüş histolojik veya non-invazif kriterlere göre (EASL, AASLD) HSK tanıs1 olan hastalar çalışmaya dahil edildi. Çalışmaya 377 hasta alınmış olup demografik, klinik ve laboratuar verileri retrospektif analiz edildi.

Hasta dosyalarından yaş, cinsiyet, eğitim seviyesi, alkol kullanımı, sigara kullanımı, yaşam alanı ve komorbit hastalıklar gibi demografik veriler ile HBsAg, anti-HBs, 
$\mathrm{HBeAg}$, anti-HBe, anti-HBc IgG,anti-HCV, total Anti-HDV, HBV DNA, HCV RNA, HDV RNA düzeyi ve AFP, ALT, AST, ALP, GGT, kreatinin, albumin, total bilirubin, hemogram, ferritin, sedimantasyon, PTZ-INR değerleri ve ultrasonografi, bilgisayarlı tomografi ve magnetik rezonans görüntüleme sonuçları incelendi.

HBV DNA düzeyi için hastanemiz laboratuarı alt sınırı; $20 \mathrm{IU} / \mathrm{ml}$, lineer aralığı; $20-1.7 \times 10^{8} \mathrm{IU} / \mathrm{ml}$ idi. $(1 \mathrm{IU} / \mathrm{ml}=5.82$ kopya/ml). HDV RNA alt sınıri; 400 kopya/ml, lineer aralığı: $400-4 \times 10^{7} \mathrm{kopya} / \mathrm{ml}$ idi. HCV RNA alt sınırı; $15 \mathrm{IU} / \mathrm{ml}$, lineer aralı̆g 115 $6.9 \times 10^{7} \mathrm{IU} / \mathrm{ml}$ idi $(1 \mathrm{IU} / \mathrm{ml}=2.7 \mathrm{kopya} / \mathrm{ml})$.

Karaciğer sirozu tanısı belirli kriterlere göre konulmuştu. $\mathrm{Bu}$ kriterler; serum albumin düzeyinin $3 \mathrm{~g} / \mathrm{dl}$ 'nin altında olması, serum bilirubin düzeyinin $4 \mathrm{mg} / \mathrm{dl}$ 'nin üzerinde olması, protrombin zamanının 3 sn'den uzun olmas1, trombosit sayısinın $150000 \mathrm{~K} / \mathrm{uL}$ 'nin altında olması, histolojik veya radyolojik olarak karaciğer sirozu bulgularının olmasıydı. Dekompanse karaciğer sirozlu hastalar ise asit, varis kanaması ve hepatik ensefalopati öyküsü olan hastalar olarak belirlendi.

Veriler SPSS (Statistical Package for Social Sciences) 18 yazılım programı yardımıyla hazırlanan veri tabanına girildikten sonra testler bu program üzerinde yapıldı. Sayısal parametreler için Student's t-test ve Mann-Wittney U testi, sayisal olmayan parametreler için ki-kare testi uyguland. P değeri $<0.05$ olanlar anlamlı olarak kabul edildi.

\section{BULGULAR}

\section{Epidemiyolojik bulgular}

HSK tanısı konan 377 hasta çalışmaya alındı. Hastalar etiyolojik faktörlere bağlı olarak dört gruba ayrıldı. Grup A; 218 HBV'ye bağlı HSK (\%57.8), grup B; 59 HDV'ye bağlı HSK (\%15.6), grup C; 31 HCV'ye bağlı HSK (\%8.2), grup D; 69 non-viral nedenlere bağl1
HSK (\%18.3) hastalarından oluşmaktaydı. Tüm hastaların yaş ortalaması $58.70 \pm 12.50$ yıldı. HBV'ye bağlı HSK hastalarının yaş ortalaması 59.31 \pm 11.98 , HDV'ye bağlı HSK hastalarının yaş ortalaması $53.39 \pm 10.75$, nonviral nedenlere bağlı HSK hastalarının yaş ortalamas1 $58.28 \pm 14.67$, HCV'ye bağl1 HSK hastalarının yaş ortalaması ise $65.42 \pm 10.05 \mathrm{y} 11$ olup diğer gruplara göre anlamlı olarak daha yüksek bulundu $(\mathrm{p}=0.001)$. Tüm hastaların 310'u erkek, 67'si kadın hasta olup, erkekler tüm hastaların \% 82.2'sini oluşturmaktaydı. Hastaların büyük çoğunluğu şehir merkezinde yaşamakta olup, \%67.6'sının eğitim seviyesi ilkokul veya daha düşük seviyedeydi. Hastaların epidemiyolojik özellikleri tablo 1 ve 2'de verilmiştir.

\section{Laboratuar ve Klinik bulgular}

Hastaların bilinen ortalama enfeksiyon süresi 9.38 \pm 9.08 yıldı, HBV'ye bağlı HSK hastalarında 6.86 \pm 5.94 , HDV'ye bağlı HSK hastalarmda $8.39 \pm 10.31$, bu süre $\mathrm{HCV}$ enfeksiyonuna bağlı HSK hastalarında ise $10.67 \pm 8.12$ y1l olup, diğer gruplardan anlaml olarak daha yüksekti $(\mathrm{p}=0.04)$. Hastaların $\%$ 23.6's1 antiviral tedavi almaktayken, HBV'ye bağlı HSK hastalarının \%32.6's1, HCV'ye bağl1 HSK hastalarının \%16.7'si, HDV'ye bağlı HSK hastalarının ise \%51'i antiviral tedavi almış olup diğer gruplardan anlamlı olarak daha yüksek bulundu $(\mathrm{p}=0.005)$. Hastaların \%87'sinde HSK siroz zemininde gelişmiş olup, hastaların Child-Pugh skoruna bakıldığında ise A, B ve C için sırasıyla \%28, $\% 50$ ve $\% 22$ idi. Hastaların klinik özellikleri Tablo 3'te verilmiştir.

HBV'ye bağlı hastaların ortalama AFP değeri $2600.28 \pm 6652.17 \mathrm{ng} / \mathrm{ml}$, HDV'ye bağl1 hastaların $209.88 \pm 311.76 \mathrm{ng} / \mathrm{ml}$, HCV'ye bağl1 hastaların $421.96 \pm 462.99 \mathrm{ng} / \mathrm{ml}$, non-viral nedenlere bağlı hastaların 1571.46 \pm 3469.82 ng/ml olup, HBV'ye bağlı hastaların ortalama AFP değerleri anlamlı olarak daha yüksek saptand $1(p=0.008)$. Hastaların biyokimyasal ve 
hematolojik parametreleri Tablo 4'te verilmiştir.

Kronik HBV olan hastalardan iki hastada okült HBV'yle uyumlu olarak HBsAg $(-)$, anti-HBs (+) ve HBV DNA (+) olarak saptandı. HBV'ye bağlı hastaların \% 13'ünde, HDV'ye bağl1 hastaların \% 13.6'sında HBeAg pozitifliği saptandı. HBV'ye bağlı hastaların \% 78.4'ünde, HDV'ye bağlı hastaların \% 78'inde anti-HBe pozitifliği saptandı. HBV'ye bağl1 hastaların \% 84.1'inde, HDV'ye bağl1 hastaların \% 91.5'inde, Anti-HBc IgG pozitifti. HBV ve HDV grupları arasında; HBsAg, AntiHBs, HBeAg, Anti-HBe, Anti-HBc IgG pozitifliği açısından anlamlı fark bulunmadı. Hastaların serolojik ve virolojik parametreleri Tablo 5 ve 6'da verilmiştir.

HBV'ye bağlı HSK hastalarının \% 52.4'ünde, HCV'ye bağlı HSK hastalarının \% 41.9'unda, non-viral nedenlere bağlı HSK hastalarının \% 46.4'ünde sadece sağ lob tutulumu vard1, bu oran HDV'ye bağl1 HSK hastalarında \% 71.4 olup anlaml 1 derecede daha yüksek bulundu ( $\mathrm{p}=0.01$ ). HBV'ye bağlı HSK hastalarında maksimum tümör çap $1(\mathrm{~cm})$ 6.85 66.94, HDV'ye bağlı HSK hastalarında 5.28 \pm 3.54 , HCV'ye bağlı HSK hastalarında $5.39 \pm 2.99$, non-viral nedenlere bağl $\mathrm{HSK}$ hastalarında $6.6 \pm 3.65 \mathrm{~cm}$ olup, maksimum tümör çapı açısından gruplar arasında anlamlı fark bulunmadı. Hastaların tümör özellikleri Tablo 7'de verilmiştir.

\section{TARTIŞMA}

Çalışmamızda hastaların yaş ortalaması $58.70 \pm 12.50$ yıl olarak bulundu. Yalçın ve ark. (10) yaptığı çalışmada hastaların ortalama yaşı $57.67 \pm 12.03$ y1l olarak bulunmuş olup çalışmamızla uyumluydu. Çalışmamızda gruplar arasında HCV'ye bağlı HSK hastalarında yaş ortalaması $65.42 \pm 10.05 \mathrm{y} 11$ olup, diğer gruplardan anlamlı olarak daha yüksekti ( $\mathrm{p}=0.001)$. Bu sonuç; HCV'ye bağlı HSK'nın daha ileri yaşta ortaya çıktığını göstermektedir. HCV taşıyıcılarının çoğu yetişkin yaşlarda virüsle enfekte olurken HBV taşıyıcıları daha genç yaşlarda enfekte olmaktadır (12). Gambia'da yapılan başka bir çalışmada HCV ile ilişkili HSK hastaları HBV ile ilişkili HSK hastalarına göre yaklaşık 10 yıl daha yaşlı bulunmuştur (13). HDV koenfeksiyonu ile tek başına HBV enfeksiyonunun karşılaştırıldığ 1 bir çalışmada HDV ko-enfeksiyonu anlamlı düzeyde daha erken yaşlarda HSK gelişimi ile ilişkili bulunmuş olup, bu fark yaklaşık 10 yıl olarak tespit edilmiştir (14). Çalışmamızda HDV'ye bağlı HSK gelişen hastaların yaş ortalaması $53.39 \pm 10.75$ y1l olup, en genç hastalar bu gruptayd 1 ve literatür ile uyumluydu. HDV infeksiyonuna bağlı gelişen HSK'nın daha erken yaşlarda görülmesinin nedeni bu infeksiyona bağlı olarak daha ciddi nekroinflamatuar ve fibrotik aktivitenin görülmesi, bu hastalarda daha erken ve progresif siroz tablosunun görülmesi olabilir.

HSK erkeklerde kadınlara göre daha fazla görülmektedir. Bu fark yüksek insidanslı bölgelerde düşük insidanslı bölgelere göre daha fazladır (15). Erkeklerde kadınlara göre daha yüksek oranda HSK görülmesinin erkeklerdeki daha yüksek sigara ve alkol kullanım oranları ve/veya östrojen ve androjen faliyetleriyle ilişkili olabileceği ileri sürülmüştür (12). Yalçın ve arkadaşlarının (10) çalışmasında erkek/kadın oranı 5.8:1 olarak tespit edilmiştir. Çalışmamızda erkek/kadın oranı 4.6:1 olarak bulundu ve Türkiye verileriyle uyumluydu.

Çalışmamızda vakaların \%57.8'inden HBV sorumlu olup, bu sonuç ülkemizde ve dünyada yapılan diğer çalışmalarla uyumludur. ABD'de HSK vakalarının \%50-80'inden HBV'nin sorumlu olduğu tahmin edilmektedir (16-17). Global olarak tüm karaciğer kanserlerinin \%54'ünün HBV'ye bağl1 olabileceği tahmin edilmektedir (18). Yalçın ve ark. (10) yaptı̆̆ hastaları \%45'inde HBV, \%29'unda HDV etiyolojik faktör olarak bulunmuştur . Türkiye'de yapılan başka bir çalışmada HSK 
tanılı hastaların \%44.4'ünde HBV bulunmuş̧tur (19).

HBV ve HCV dışındaki faktörlerle meydana gelen HSK'nın Asya' daki oranı \% 120'dir (20). Yalçın ve ark. (10) non-viral nedenlere bağlı HSK oranı \% 10 olarak bulunmuştur. Türkiye'de yapılan başka bir çalışmada da non-viral nedenlere bağlı HSK oranı \% 14.5 olarak bulunmuştur (21). Bizim çalışmamızda non-viral nedenlere bağlı HSK hastalarının oranı \% 18.3 olarak bulundu ve Asya verileriyle uyumluydu.

Çalışmamızda HBV'ye bağlı HSK hastalarının \% 89.7'sinde, HDV'ye bağlı HSK hastalarının \% 93.1'inde, HCV'ye bağlı HSK hastalarının \% 90.3'ünde, non-viral nedenlere bağlı HSK hastalarının ise \% 73.9'unda siroz bulunmaktaydi. Bu sonuç; non-viral nedenlere bağlı gelişen HSK'nın viral sebeplere göre daha az sıklıkla siroz zemininde geliştiğini göstermektedir $(p=0.002)$. HBV ve HCV ile ilişkili HSK olgularının çoğu siroz zemininde meydana gelmektedir (22). Çalışmamızda ortalama Child-Pugh ve MELD skoru viral sebeplere bağlı HSK hastalarında daha yüksek bulundu $(\mathrm{p}=0.01)$, bu sonuç viral sebeplere bağlı HSK hastalarında karaciğer yetmezliği bulgularının daha şiddetli olduğunu desteklemektedir. Viral grupta HCV ve HDV'ye bağlı HSK hastalarında Child-Pugh skoru diğer gruplardan anlamlı bir şekilde daha yüksek bulundu $(p=0.02)$. Tüm gruplarda ortalama Child-Pugh skoru 7-8 olarak bulundu. Türkiye'de yapılan bir çalışmada HSK tanılı hastaların büyük çoğunluğu Child B-C olarak tespit edilmiştir (21). Bu bulgular ülkemizde HSK tanıs1 konduğunda hastaların yüksek Child-Pugh skoru olduğunu göstermektedir.

Çalışmamızda HBV'ye bağlı HSK hastalarında ortalama AFP değerleri diğer gruplara göre anlamlı bir şekilde daha yüksek bulundu $(\mathrm{p}=0.008)$. HSK tanis1 konan hastalarla yapılan bir çalışmada AFP seviyeleri yüksek olabilirken hastaların büyük kısmında normal olarak bulunmuştur (23). Çin'de yapılan bir çalışmada küçük HSK'ların \% 40'1nda serum AFP konsantrasyonları normal bulunmuştur (24). HSK vakalarında AFP değerlerinin normal olabileceği görüldüğünden HSK tanısında kullanımını kısıtlamıştır.

Çalışmamızda HBV'ye bağlı HSK hastalarının \% 81.9'una, HDV'ye bağlı HSK hastalarının \% 88.1'ine, HCV'ye bağlı HSK hastalarının \% 93.5'ine ve non-viral sebeplere bağlı HSK hastalarının \% 72.5'ine biyopsisiz tanı konuldu. Çalışmamızda en fazla HCV'ye bağlı HSK hastalarına biyopsisiz tanı konuldu $(\mathrm{p}=0.03)$. Görüntüleme teknolojisindeki gelişmeler nedeniyle, radyoloji HSK tanısında oldukça spesifikleşmiştir. Türkiye'de yapılan bir çalışmada hastaların \% 66.51'ine biyopsisiz tanı konulduğu rapor edilmiştir (10). Ülkemizde HSK etyolojisinde çoğunlukla viral sebeplerin olmas1, radyolojik bulgularla beraber yeterli tanı kriterlerini oluşturduğundan çoğunlukla, hastalara biyopsiye gerek kalmadan tan1 konulabilmektedir. Ayrıca ülkemizde genellikle HSK ileri evrede tanı almaktadır, bu yüzden tanı için, radyolojik tetkikler çoğu zaman yeterli olmaktadır.

Sonuç olarak; viral hepatitler, HSK gelişiminde en önemli risk faktörü olup, HSK sıklıkla siroz zemininde gelişmektedir. $\mathrm{Bu}$ nedenle kronik viral hepatit tanılı hastaların ve karaciğer sirozu olan hastaların takip ve tedavisi büyük önem taşımaktadır. Bölgemizde HSK'l1 hastaların anti-viral tedavi kullanma oranlarının düşüklüğü ve yüksek Child-Pugh skoru ile başvurmaları bu konunun önemini koruyan ciddi bir sağl1k problemi olduğunu göstermektedir. Viral hepatitler ile ilgili farkındalığın arttırılması, aşı programlarına hastaların teşviki ile HSK prevalansının azaltılacağı aşikar olup, siroz gelişen hastalarda da düzenli takip programlarıyla daha erken evrede HSK tanısı konup daha efektif tedavi seçenekleriyle uzun süreli sağkalım elde edilecektir. 
Tablo 1: Hastaların epidemiyolojik özellikleri

\begin{tabular}{|l|c|}
\hline & Değerler \\
\hline Yaş (yıl, ortalama) & $58.70 \pm 12.50$ \\
\hline Cinsiyet (erkek, \%) & $310(\% 82.2)$ \\
\hline HBV'li hasta sayısı & $218(\% 57.8)$ \\
\hline HDV'li hasta sayıs1 & $59(\% 15.6)$ \\
\hline HCV'li hasta sayısı & $31(\% 8.2)$ \\
\hline Non-viral hasta sayıs1 & $69(\% 18.3)$ \\
\hline Kent/kırsal (kent, \%) & $275(\% 72.9)$ \\
\hline Eğitim seviyesi, düşük/ yüksek (ilkokul ve altı, \%) & $255(\% 67.6)$ \\
\hline Ailede hepatit öyküsü (Var/yok) & $78(\% 20.7)$ \\
\hline Ailede HSK öyküsü (Var/yok) & $20(\% 5.3)$ \\
\hline Diyabet öyküsü (Var/yok) & $75(\% 19.9)$ \\
\hline Sigara kullanımı (Var/yok) & $198(\% 52.5)$ \\
\hline Alkol kullanımı (Var/yok) & $17(\% 4.5)$ \\
\hline
\end{tabular}

Tablo 2: Gruplar arası epidemiyolojik özelliklerin karşılaştırılması

\begin{tabular}{|l|l|l|l|l|l|}
\hline & $\begin{array}{l}\text { HBV } \\
(\mathbf{n = 2 1 8})\end{array}$ & $\begin{array}{l}\text { HDV } \\
(\mathbf{n = 5 9 )}\end{array}$ & $\begin{array}{l}\text { HCV } \\
(\mathbf{n = 3 1})\end{array}$ & $\begin{array}{l}\text { Non-viral } \\
(\mathbf{n = 6 9})\end{array}$ & P değeri \\
\hline Yaş (yıl) & $59.31 \pm 11.98$ & $53.39 \pm 10.75$ & $65.42 \pm 10.05$ & $58.28 \pm 14.67$ & $\mathrm{P}=0.001$ \\
\hline Cinsiyet (erkek, \%) & $\% 86.2$ & $\% 78.0$ & $\% 87.1$ & $\% 71.0$ & $\mathrm{P}=0.002$ \\
\hline Kent/kırsal (kent, \%) & $\% 73.7$ & $\% 82.1$ & $\% 74.2$ & $\% 75.4$ & $\mathrm{P}=0.63$ \\
\hline $\begin{array}{l}\text { Eğitim seviyesi, düşük/yüksek } \\
\text { (ilkokul ve altı \%) }\end{array}$ & $\% 77.1$ & $\% 75.0$ & $\% 83.9$ & $\% 85.5$ & $\mathrm{P}=0.37$ \\
\hline Ailede hepatit öyküsü (Var/yok) & $\% 29.8$ & $\% 33.3$ & $\% 13.3$ & $\% 22.2$ & $\mathrm{P}=0.21$ \\
\hline Ailede HSK öyküsü (Var/yok) & $\% 7.3$ & $\% 9.8$ & $\% 0.0$ & $\% 3.4$ & $\mathrm{P}=0.24$ \\
\hline Diyabet öyküsü (Var/yok) & $\% 20.1$ & $\% 16.9$ & $\% 33.3$ & $\% 18.2$ & $\mathrm{P}=0.29$ \\
\hline Sigara (Var/yok) & $\% 67.2$ & $\% 52.0$ & $\% 63.3$ & $\% 50.7$ & $\mathrm{P}=0.05$ \\
\hline Alkol (Var/yok) & $\% 6.2$ & $\% 4.0$ & $\% 6.7$ & $\% 3.0$ & $\mathrm{P}=0.73$ \\
\hline
\end{tabular}

Tablo 3: Hastaların klinik özellikleri

\begin{tabular}{|c|c|c|c|c|c|}
\hline & $\begin{array}{l}\text { HBV } \\
(n=218)\end{array}$ & $\begin{array}{l}\text { HDV } \\
(n=59)\end{array}$ & $\begin{array}{l}\text { HCV } \\
(n=31)\end{array}$ & $\begin{array}{l}\text { Non-viral } \\
(n=69)\end{array}$ & P değeri \\
\hline İnfeksiyon süresi (y1l) & $6.86 \pm 5.94$ & $8.39 \pm 10.31$ & $10.67 \pm 8.12$ & - & $\mathrm{P}=0.04$ \\
\hline Anti-viral tedavi alımı (Var/yok) & $\% 32.6$ & $\% 51.0$ & $\% 16.7$ & - & $\mathrm{P}=0.005$ \\
\hline Siroz varlığ1 (Var/yok) & $\% 89.7$ & $\% 93.1$ & $\% 90.3$ & $\% 73.9$ & $\mathrm{P}=0.002$ \\
\hline Portal ven trombozu (Var/yok) & $\% 35.9$ & $\% 30.8$ & $\% 35.5$ & $\% 29.4$ & $\mathrm{P}=0.75$ \\
\hline MELD, skor & $13.01 \pm 5.33$ & $13.08 \pm 4.98$ & $12.00 \pm 3.43$ & $10.91 \pm 4.35$ & $\mathrm{P}=0.01$ \\
\hline Child-Pugh, skor & $7.99 \pm 2.04$ & $8.24 \pm 2.06$ & $8.23 \pm 2.20$ & $7.28 \pm 1.58$ & $\mathrm{P}=0.02$ \\
\hline
\end{tabular}


Tablo 4: Hastaların hematolojik ve biyokimyasal testleri

\begin{tabular}{|c|c|c|c|c|c|}
\hline & HBV $(n=218)$ & HDV $(n=59)$ & $\operatorname{HCV}(n=31)$ & Non-viral $(n=69)$ & P değeri \\
\hline $\begin{array}{l}\text { Hemoglobin } \\
(\mathrm{g} / \mathrm{dl})\end{array}$ & $12.43 \pm 2.17$ & $12.58 \pm 2.29$ & $11.97 \pm 2.03$ & $11.84 \pm 2.30$ & $\mathrm{P}=0.14$ \\
\hline $\begin{array}{l}\text { Trombosit } \\
(\mathrm{K} / \mathrm{uL})\end{array}$ & $\begin{array}{l}184318.76 \pm \\
202451.47\end{array}$ & $\begin{array}{l}141547.46 \pm \\
85712.87\end{array}$ & $\begin{array}{l}158901.94 \pm \\
91756.27\end{array}$ & $\begin{array}{l}229055.07 \pm \\
138789.59\end{array}$ & $\mathrm{P}=0.03$ \\
\hline Ferritin (ng/ml) & $279.14 \pm 292.00$ & $304.47 \pm 438.40$ & $202.48 \pm 214.41$ & $210.41 \pm 230.65$ & $\mathrm{P}=0.34$ \\
\hline PTZ, INR & $1.37 \pm 0.28$ & $1.37 \pm 0.25$ & $1.29 \pm 0.23$ & $1.23 \pm 0.22$ & $\mathrm{P}=0.001$ \\
\hline $\begin{array}{l}\text { Sedimantasyon } \\
\text { hızı }\end{array}$ & $34.48 \pm 24.72$ & $33.86 \pm 30.73$ & $31.97 \pm 21.30$ & $41.48 \pm 28.01$ & $\mathrm{P}=0.23$ \\
\hline ALT (U/L) & $78.54 \pm 67.26$ & $108.39 \pm 136.61$ & $67.03 \pm 43.36$ & $59.62 \pm 57.13$ & $\mathrm{P}=0.005$ \\
\hline AST (U/L) & $125.90 \pm 125.60$ & $127.31 \pm 144.39$ & $80.48 \pm 41.51$ & $100.22 \pm 117.00$ & $\mathrm{P}=0.13$ \\
\hline ALP (U/L) & $219.01 \pm 180.01$ & $168.24 \pm 102.13$ & $210.03 \pm 179.03$ & $280.42 \pm 315.43$ & $\mathrm{P}=0.02$ \\
\hline GGT (U/L) & $186.05 \pm 153.59$ & $168.68 \pm 182.53$ & $218.61 \pm 196.94$ & $257.36 \pm 254.88$ & $\mathrm{P}=0.02$ \\
\hline Albumin $(\mathrm{g} / \mathrm{dl})$ & $2.72 \pm 0.71$ & $2.90 \pm 0.78$ & $2.77 \pm 0.75$ & $2.97 \pm 0.66$ & $\mathrm{P}=0.07$ \\
\hline $\begin{array}{l}\text { Total bilirubin } \\
(\mathrm{mg} / \mathrm{dl})\end{array}$ & $3.04 \pm 4.35$ & $2.27 \pm 2.17$ & $2.13 \pm 2.02$ & $2.12 \pm 4.12$ & $\mathrm{P}=0.20$ \\
\hline $\begin{array}{l}\text { Kreatinin } \\
(\mathrm{mg} / \mathrm{dl})\end{array}$ & $0.92 \pm 0.57$ & $0.93 \pm 0.50$ & $0.85 \pm 0.27$ & $0.87 \pm 0.31$ & $\mathrm{P}=0.80$ \\
\hline AFP (ng/ml) & $2600.28 \pm 6652.17$ & $209.88 \pm 311.76$ & $421.96 \pm 462.99$ & $1571.46 \pm 3469.82$ & $\mathrm{P}=0.008$ \\
\hline
\end{tabular}

Tablo 5: Hastaların serolojik ve virolojik testleri

\begin{tabular}{|l|l|l|l|}
\hline & HBV & HDV & P değeri \\
\hline HBsAg pozitifliği, n (\%) & $216(\%$ 99.1) & $59(\% 100)$ & $\mathrm{P}=0.61$ \\
\hline Anti-HBs pozitifliği, n (\%) & $9(\%$ 4.1) & $2(\% 3.4)$ & $\mathrm{P}=0.57$ \\
\hline HbeAg pozitifliği, n (\%) & $27(\% 13.0)$ & $8(\% 13.6)$ & $\mathrm{P}=0.52$ \\
\hline Anti-HBe pozitifliği, n (\%) & $163(\% 78.4)$ & $46(\% 78.0)$ & $\mathrm{P}=0.53$ \\
\hline Anti-HBc IgG pozitifliği, n (\%) & $175(\% 84.1)$ & $54(\%$ 91.5) & $\mathrm{P}=0.10$ \\
\hline HBV DNA, pozitifliği, n (\%) & $83(\% 78.0)$ & $25(\%$ 64.4) & $\mathrm{P}=0.03$ \\
\hline HBV DNA, Log10 kopya/ml (ortalama) & $4.31 \pm 2.23$ & $2.92 \pm 1.12$ & $\mathrm{P}=0.001$ \\
\hline
\end{tabular}


Tablo 6: Hastaların serolojik ve virolojik testleri

\begin{tabular}{|c|c|c|c|c|}
\hline & $\begin{array}{c}\text { HBV DNA } \\
\text { pozitifliği n/\% }\end{array}$ & $\begin{array}{c}\text { HDV RNA } \\
\text { pozitifliği n/\% }\end{array}$ & $\begin{array}{c}\text { HCV RNA } \\
\text { pozitifliği n/\% }\end{array}$ & P değeri \\
\hline $\begin{array}{l}\text { Aktif viral replikasyon oran1, } \\
\mathrm{n} / \%\end{array}$ & $83(\% 78.0)$ & $25(\% 26.5)$ & $19(\% 95.0)$ & $\mathrm{P}=0.05$ \\
\hline $\begin{array}{l}\text { Viral replikasyon düzeyi (Log10 } \\
\text { kopya/ml (ortalama) }\end{array}$ & $\begin{array}{l}4.31 \pm 2.23 \\
\log 10 \quad \mathrm{kopya} / \mathrm{ml} \\
\text { (ortalama) }\end{array}$ & $\begin{array}{l}3.06 \pm 0.97 \\
\log 10 \quad \text { kopya/ml } \\
\text { (ortalama) }\end{array}$ & $\begin{array}{l}5.51 \pm 1.53 \\
\log 10 \quad \mathrm{kopya} / \mathrm{ml} \\
\text { (ortalama) }\end{array}$ & $\mathrm{P}=0.001$ \\
\hline
\end{tabular}

Tablo 7: Hastaların tümör özellikleri

\begin{tabular}{|l|l|l|l|l|l|}
\hline & $\begin{array}{l}\text { HBV } \\
(\mathbf{n = 2 1 8})\end{array}$ & $\begin{array}{l}\text { HDV } \\
(\mathbf{n = 5 9 )}\end{array}$ & $\begin{array}{l}\text { HCV } \\
(\mathbf{n = 3 1})\end{array}$ & $\begin{array}{l}\text { Non-viral } \\
(\mathbf{n = 6 9})\end{array}$ & P değeri \\
\hline $\begin{array}{l}\text { Sadece sağ lob tutulumu } \\
\text { (Var/yok) }\end{array}$ & $\% 52.4$ & $\% 71.4$ & $\% 41.9$ & $\% 46.4$ & $\mathrm{P}=0.01$ \\
\hline $\begin{array}{l}\text { Sadece sol lob tutulumu } \\
\text { (Var/yok) }\end{array}$ & $\% 12.7$ & $\% 8.9$ & $\% 9.7$ & $\% 13$ & $\mathrm{P}=0.84$ \\
\hline Bi-lobüle tutulum (Var/yok) & $\% 34.6$ & $\% 18.6$ & $\% 48.4$ & $\% 40.6$ & $\mathrm{P}=0.01$ \\
\hline Uninodüler tutulum (Var/yok) & $\% 42.5$ & $\% 48.2$ & $\% 41.9$ & $\% 42.0$ & $\mathrm{P}=0.87$ \\
\hline Multinodüler tutulum (Var/yok) & $\% 57.0$ & $\% 49.2$ & $\% 58.1$ & $\% 58.0$ & $\mathrm{P}=0.71$ \\
\hline $\begin{array}{l}\text { Maksimum tümör çap1 (cm) } \\
\text { Biyopsisiz tanı (Var/yok) }\end{array} \% 8.85 \pm 6.94$ & $5.28 \pm 3.54$ & $5.39 \pm 2.99$ & $6.6 \pm 3.65$ & $\mathrm{P}=0.20$ \\
\hline Biyopsili tanı (Var/yok) & $\% 18.1$ & $\% 88.1$ & $\% 93.5$ & $\% 72.5$ & $\mathrm{P}=0.03$ \\
\hline
\end{tabular}

\section{REFERANSLAR}

1. Ferlay J, Soerjomataram I, Dikshit R et al. Cancer incidence and mortality worldwide: sources, methods and major patterns in GLOBOCAN 2012. Int J Cancer 2015;136(5):E359-86.

2. Akinyemiju $\mathrm{T}$, Abera $\mathrm{S}$, Ahmed $\mathrm{M}$ et al. The Burden of Primary Liver Cancer and Underlying Etiologies From 1990 to 2015 at the Global, Regional, and National Level: Results From the Global Burden of Disease Study 2015. JAMA Oncol 2017;3(12):1683-91.

3. Katherine A. McGlynna, Jessica L. Petricka, and W. Thomas London. Global epidemiology of hepatocellular carcinoma: an emphasis on demographic and regional variability. Clin Liver Dis 2015;19(2):223-38.
4. Colombo M, de Franchis R, Del Ninno E et al. Hepatocellular carcinoma in Italian patients with cirrhosis. N Engl J Med 1991;325(10):675-80.

5. Tsukuma H, Hiyama $\mathrm{T}$, Tanaka $\mathrm{S}$ et al. Risk factors for hepatocellular carcinoma among patients with chronic liver disease. N Engl J Med 1993;328(25):1797-81

6. Jemal A, Bray F, Center MM et al. Global cancer statistics. CA Cancer J Clin 2011;61(2):69-90.

7. Davila JA, Morgan RO, Shaib Y et al. Hepatitis $\mathrm{C}$ infection and the increasing incidence of hepatocellular carcinoma: a population-based study. Gastroenterology 2004;127(5):1372-80.

8. Maucort-Boulch D, de Martel C et al. Fraction and incidence of liver cancer attributable to hepatitis $\mathrm{B}$ and $\mathrm{C}$ viruses worldwide. Int $\mathrm{J}$ Cancer 2018;142(12):2471-7 
9. Uzunalimoglu O, Yurdaydin C, et al. Risk factors for hepatocellular carcinoma in Turkey. Dig Dis Sci 2001;46(5):1022-8.

10. Yalçın $\mathrm{K}$ et al. Clinical and Epidemiological Characteristics of Hepatocellular Carcinoma Cases in East and Southeastern Region of Turkey:A Multicenter Retrospective Study. Turkiye Klinikleri J Med Sci 2013;33(3):80613.

11. Omata M, Lesmana LA, Tateishi R, et al. Asian Pacific Association for the Study of the Liver consensus recommendations on hepatocellular carcinoma. Hepatol Int 2010;4:439-74.

12. El-Serag HB, Rudolph KL. Hepatocellular carcinoma: epidemiology and molecular carcinogenesis. Gastroenterology 2007;132:2557-76.

13. Kirk GD, Lesi O.A., Mendy $M$ et al. The Gambia Liver Cancer Study: Infection with hepatitis B and C and the risk of hepatocellular carcinoma in West Africa. Hepatology 2004;39:211-9.

14. Oliveri F, Brunetto MR, Actis GC, Bonino F. Pathobiology of chronic hepatitis virus infection and hepatocellular carcinoma (HCC). Ital J Gastroenterol 1991;23(8):498-502

15. Siegel R, Naishadham D, Jemal A. Cancer statistics, 2013. CA Cancer J Clin 2013;63(1):11-30.

16. El-Serag HB. Hepatocellular carcinoma. N Engl J Med 2011;365:1118-27.

17. El-Serag HB. Epidemiology of hepatocellular carcinoma in USA. Hepatol Res. 2007;37 Suppl 2:S88-94.
18. Parikh A, Taouli B. Imaging of hepatocellular carcinoma: current concepts. Recent Results Cancer Res 2013;190:33-55.

19. Alacacioglu A, Somali I, Simsek I, et al. Epidemiology and Survival of Hepatocellular Carcinoma in Turkey: Outcome of Multicenter Study. Jpn J Clin Oncol 2008;38(10)683-8.

20. Farrell GC, Chan HL, Yuen MF et al. AsiaPacific Working Party on Prevention of Hepatocellular Carcinoma. Prevention of hepatocellular carcinoma in the Asia- Pacific region: consensus statements. J Gastroenterol Hepatol 2010;25(4):657-63.

21. Kaya Ö. Hepatosellüler kanserli hastaların klinik ve epidemiyolojik özellikleri ve bunların klinik seyir ve prognoz üzerine etkileri. Dicle Üniversitesi Tıp Fakültesi İç Hastalıkları Uzmanlık Tezi, Diyarbakır 2011

22. Beasley RP, Hwang LY, Lin CC, Chien CS. Hepatocellular carcinoma and hepatitis B virus: a prospective study of 22,700 men in Taiwan. Lancet 1981;2(8256,9:1129-33.

23. Benson $\mathrm{AB}$, D'Angelica MI et al. Hepatobiliary cancers, version 2.2014. J Natl Compr Canc Netw 2014; 12: 1152-82

24. Chen DS, Sung JL, Sheu JC, et al. Serum alpha-fetoprotein in the early stage of human hepatocellular carcinoma. Gastroenterology 1984;86(6):1404-9. 